\title{
Development and characterization of an immunoaffinity column for the detection of danofloxacin residues in milk samples
}

\author{
Rui NIU ${ }^{1 \dagger}$, Yamei YANG ${ }^{1 \dagger}$, Yadan $\mathrm{WANG}^{1}$, Shilong $\mathrm{LUO}^{2}$, Cheng $\mathrm{ZHANG}^{2}$, Yun WANG ${ }^{1 \star}$
}

\begin{abstract}
In this study, an immunoaffinity column was prepared by covalently coupling of polyclonal antibody against danofloxacin (DAN) with chitosan microparticles and its potential application to selective extraction of DAN from food samples was also evaluated. The produced antibody exhibited high sensitivity, with an $\mathrm{IC}_{50}$ value of $4.56 \mathrm{ng} / \mathrm{mL}$ towards DAN, and good specificity, with less than $0.5 \%$ of cross-reactivity towards DAN structurally related compounds. The developed immunoaffinity column had an approximate binding capacity of $2300 \mathrm{ng} / \mathrm{mL}$ gel and a relative standard deviation (RSD) of $3.7 \%$ among columns. The immunoaffinity columns were then challenged with DAN-fortified milk samples, recoveries of DAN were found to be in the range of $83.8 \%$ to $98.8 \%$, indicating the prepared immunoaffinity column is suitable for use as an efficient extraction method to detect DAN residues in food products.
\end{abstract}

Keywords: danofloxacin; immunoaffinity chromatography; clean-up; residual detection.

Practical Application: The prepared immunoaffinity column can be used to samples clean-up and food analysis.

\section{Introduction}

Danofloxacin (DAN), one of the most important fluoroquinolones, has been widely used as veterinary medicines for farm animals to prevent and treat various infection diseases. Its bactericidal activity involves the selective inhibition two bacterial enzymes, DNA gyrase and topoisomerase, that play an essential role in bacterial DNA replication (Martinez et al., 2006). Unfortunately, the widespread use of DAN in food-producing animals has caused public concern because of the development of antimicrobial resistance and a potential risk of residues in foodstuffs of animal origin (Lara et al., 2006). Adverse effects reported by long-term exposure to fluoroquinolones include central nervous system toxicity, cardio toxicity, arthropathy and tendon toxicity (Licata et al., 2012). For these reasons, the employment of fluoroquinolones in animal production is regulated and maximum residue limits (MRLs) have been established by the European Union (Regulations CE No. 37/2010). The MRLs for several fluoroquinolones such as DAN, enrofloxacin (ENR) and ciprofloxacin (CIP) in bovine milk is in the range of $30-100 \mu \mathrm{g} / \mathrm{kg}$ (Bulletin of the Ministry of Agriculture of the People's Republic of China, No. 235, 2002). Therefore, there is an urgent need to develop a simple, effective and accurate analytic method to quantify DAN residues in livestock products.

Various analytical methods such as liquid chromatography, liquid chromatography-tandem mass spectrometry and capillary electrophoresis have been developed for the determination of fluoroquinolones residues (Stoilova et al., 2013; Xu et al., 2015; Yao et al., 2015; Dorival-García et al., 2016). Due to the trace level of the target analytes and the complexity of the real sample matrices, a sample pretreatment step is required prior to the instrumental analysis, aiming to clean up the matrices, isolate the analyte, and render them in a form that is compatible with analytical systems. The majority of current clean-up methods are based on liquid-liquid extraction, solid phase extraction and matrix solid phase dispersion (Huet et al., 2006; Li et al., 2009; Wang et al., 2009). These approaches are far from satisfactory for analytical purpose in terms of high selectivity, reproducibility, small amounts of organic solvents and time saving (Şenyuva \& Gilbert, 2010). Immunoaffinity chromatography takes the advantage of specific and reversible interaction between antibody and the analyte, and enables selective extraction and enrichment of individual compounds or classes of compounds in one step (Şenyuva \& Gilbert, 2010; Pichon \& Combes, 2016). In the last decade, the application of immunoaffinity chromatography for a variety of samples pretreatment in mycotoxins (Longobardi et al., 2013; Marley et al., 2015; Wilcox et al., 2015; Zhang et al., 2016), veterinary drugs (Mei et al., 2014; Sun et al., 2016; Yang et al., 2016) and pesticides (Esteve-Turrillas et al., 2011; Xu et al., 2012) residues analyses have been reported.

Chitosan is a natural polysaccharide and has been successfully used as a promising polymer for the chromatography matrix support (Wang et al., 2011; Anitha et al., 2014; Vakili et al., 2014; Yang et al., 2016). Therefore, the objective of this study is to: i) prepare an immunoaffinity column by employing anti-DAN polyclonal antibody and chitosan microparticles; ii) characterize and evaluate the obtained immunoaffinity column for the selective extraction and determination of DAN in food samples. 


\section{Materials and methods}

\subsection{Chemicals and reagents}

Chitosan microparticles were prepared by our laboratory according to previous report (Yang et al., 2016). DAN, ENR, norfloxacin (NOR), triethylamine, N, N-Dimethylformamide (DMF), 1-ethyl-(3-dimethylaminopropyl) carbodiimide hydrochloride (EDC), N-hydroxysuccinimide (NHS), incomplete Freund's adjuvant (iFA) and complete Freund's adjuvant (cFA) were obtained from Sigma-Aldrich (St. Louis, MO, USA). High-performance liquid chromatography (HPLC)-grade methanol was purchased from Fisher Scientific, Inc. (Pittsburgh, USA). Bovine serum albumin (BSA), CIP, ofloxacin (OFL), Peroxidase-conjugated Goat Anti-Rabbit IgG and EL-TMB Chromogenic Reagent kit were purchased from Sangon Biotech Co., Ltd (Shanghai, China). All other chemicals used were of analytical grade and supplied by Sinopharm Chemical Reagent Co., Ltd (Shanghai, China).

\subsection{Synthesis of DAN-BSA conjugates}

DAN immunogen was prepared via a modified EDC/NHS method (Lu et al., 2006). In brief, $20 \mathrm{mg} \mathrm{DAN,} 12.5 \mathrm{mg} \mathrm{EDC} \cdot \mathrm{HCl}$ and $10 \mathrm{mg}$ NHS were dissolved in $1 \mathrm{~mL}$ DMF followed by agitation at room temperature for $1 \mathrm{~h}$. The mixture was added into $9 \mathrm{~mL}$ BSA solution $(4.5 \mathrm{mg} / \mathrm{mL})$ dropwise and kept under gentle stirring for 3 hours at $4{ }^{\circ} \mathrm{C}$. The solution was then dialyzed against phosphate buffer saline (PBS) for three days at $4{ }^{\circ} \mathrm{C}$ to remove the uncoupled hapten. After centrifugation at $9000 \mathrm{rpm}$ for $30 \mathrm{~min}$, the supernatant was then collected and freeze-dried to get DAN-BSA conjugates.

\subsection{Generation and purification of antibodies}

Two male New Zealand white rabbits (about $2 \mathrm{~kg}$ each) were used to generate polyclonal antibody as previously described (Chen et al., 2009). For the first immunization, $1 \mathrm{mg}$ DAN-BSA formulated in $1 \mathrm{~mL} c F A$ was subcutaneously injected at multiple sites on the back of the rabbit, and the following four immunizations were administered at three-week intervals using a mixture of immunogen in iFA. The titer evaluation of the antiserum was performed using an indirect ELISA method described below.
Once the protocol of immunization was found satisfactory to elicit the targeted antibodies, larger amounts of antiserum were collected by centrifuging the blood. The polyclonal antibodies from antiserum were purified by caprylic acid and ammonium sulfate precipitation and stored at $-20{ }^{\circ} \mathrm{C}$ for use.

\subsection{ELISA procedure}

For enzyme linked immunosorbent assay (ELISA), 96-well polystyrene microtiter plate was coated with $100 \mu \mathrm{L} /$ well coating antigen (DAN-OVA) solution dissolved in $0.05 \mathrm{M}$ carbonate buffer ( $\mathrm{pH} 9.6$ ) overnight at $4^{\circ} \mathrm{C}$, then washed with $350 \mu \mathrm{L} /$ well PBST (PBS buffer containing 0.05\% Tween-20) for 3 times. Uncoated sites were blocked with $0.2 \%$ gelatin and the plate was incubated at $37^{\circ} \mathrm{C}$ for 1 hour. After the plate was washed as described above, $50 \mu \mathrm{L}$ of the optimal antibody dilution and $50 \mu \mathrm{L}$ of diluted DAN standard solution were subsequently added followed by 1 hour of incubation at $37^{\circ} \mathrm{C}$. After the washing procedure, $100 \mu \mathrm{L} /$ well peroxidase conjugated goat anti-rabbit IgG was added before incubation for 1 hour at $37^{\circ} \mathrm{C}$. After washes, $50 \mu \mathrm{L}$ of substrate $\left(\mathrm{TMB} / \mathrm{H}_{2} \mathrm{O}_{2}\right.$ in acetate buffer $\mathrm{pH}$ 5.5) was added into each well and incubated for another $15 \mathrm{~min}$ at $37^{\circ} \mathrm{C}$, and finally $50 \mu \mathrm{L} /$ well of $2 \mathrm{~mol} / \mathrm{L} \mathrm{H}_{2} \mathrm{SO}_{4}$ was added to terminate the color development. The absorbance was measured by the microplate reader at $450 \mathrm{~nm}$. The inhibition curve was plotted as $\mathrm{A} / \mathrm{A}_{0}$ versus the DAN concentration (0.0001, 0.001, $0.01,0.1,1,10,100$ and $1000 \mathrm{ng} / \mathrm{mL}$ ), where $\mathrm{A}$ and $\mathrm{A}_{0}$ were absorbance of the wells with and without DAN, respectively. The $\mathrm{IC}_{50}$ value was estimated as the concentration of DAN that provides a $50 \%$ reduction of $\mathrm{A} / \mathrm{A}_{0}$.

\subsection{Antibody specificity determination}

Specificity of the antibody was estimated by detection of cross-reactivity (CR) toward structurally related compounds to DAN by ELISA tests, including ENR, NOR, OFL and CIP (Figure 1). The $\mathrm{IC}_{50}$ value for each compound was determined according to its inhibition curve. The $\mathrm{CR}$ values were calculated as follows: $\mathrm{CR}=\left[\mathrm{IC}_{50}\right.$ of DAN / $\mathrm{IC}_{50}$ of structurally related compound] $\times 100 \%$.

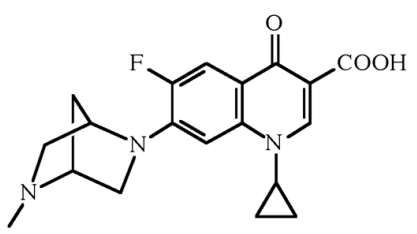

Danofloxacin (DAN)

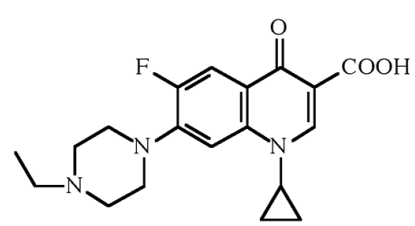

Enrofloxacin (ENR)

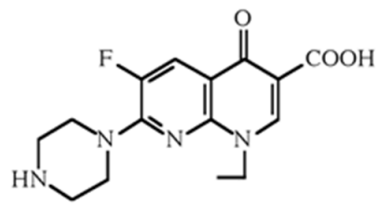

Norfloxacin (NOR)

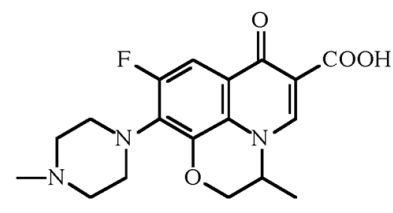

Ofloxacin (OFL)<smiles>O=C(O)c1cn(C2CC2)c2cc(N3CCNCC3)c(F)cc2c1=O</smiles>

Ciprofloxacin (CIP)

Figure 1. Structures of DAN and related fluoroquinolones evaluated in this study. DAN = danofloxacin. 


\subsection{Preparation of immunoaffinity columns}

The purified antibody was coupled to chitosan microspheres according to the method described by Yang et al. (2016). In brief, an aliquot $(2 \mathrm{~mL})$ of the antibody solution $(0.15 \mathrm{mg} / \mathrm{mL})$ was mixed with $0.5 \mathrm{~g}$ chitosan microsparticles in $5 \mathrm{~mL}$ coupling buffer $\left(0.1 \mathrm{~mol} / \mathrm{L} \mathrm{NaHCO}_{3}\right.$ containing $0.5 \mathrm{~mol} / \mathrm{L} \mathrm{NaCl}, \mathrm{pH} 8.3$ ) and the mixture was then gently agitated for 3 hours at room temperature. Subsequently, epichlorohydrin was added into the mixture to a final concentration of $20 \%$ followed by mechanically stirring for 5 hours at $37^{\circ} \mathrm{C}$. The resultant immunosorbent was washed thoroughly with distilled water and packed into a column $(10 \mathrm{~mm} \times 65 \mathrm{~mm})$ and used for the experiments described below.

\subsection{Characterization of the immunoaffinity column}

Column binding capacity was determined according to Qiao et al. (2009). In brief, a total of $4 \mu \mathrm{g}$ DAN dissolved in $10 \mathrm{~mL}$ of $0.8 \% \mathrm{NaOH} / 0.1 \mathrm{M}$ PBS ( $\mathrm{pH} 7.4$ ) was continuously applied to the immunoaffinity column ( $1 \mathrm{~mL}$ for each column). After washing with PBS, the bound DAN was eluted with $5 \mathrm{~mL}$ of $85 \%$ ethanol. All fractions in the loading, washing and eluting steps were collected and evaporated to dryness by low-pressured rotation evaporator. The residues were dissolved in acetonitrile: $0.05 \mathrm{~mol} / \mathrm{L}$ phosphoric acid (19: 81, v/v) and the DAN contents were measured by HPLC to calculate the column capacity.

To determine column-to-column variability (repeatability), $2 \mathrm{~mL}$ of DAN standard solutions $(50,100,200 \mathrm{ng} / \mathrm{mL})$ dissolved in $0.8 \% \mathrm{NaOH} / 0.1 \mathrm{M} \mathrm{PBS}$ ( $\mathrm{pH} 7.4$ ) were loaded on six immunoaffinity columns, respectively. After washing with PBS, the bound DAN was eluted with $5 \mathrm{~mL}$ of $85 \%$ ethanol and the DAN content in the effluent was determined by HPLC to calculate the relative extraction efficiency of each column.

\subsection{Extraction of DAN from real food samples by immunoaffinity column}

To further evaluate the immunoaffinity extraction for real food samples, milk samples obtained from local supermarket were respectively fortified with DAN at the final concentration of 25 and $50 \mathrm{ng} / \mathrm{g}$. Briefly, the fortified milk samples were diluted 1: 10 with $0.8 \% \mathrm{NaOH} / 0.1 \mathrm{M} \mathrm{PBS}$ ( $\mathrm{pH} 7.4$ ), centrifuged at $9000 \mathrm{~g}$ at $4{ }^{\circ} \mathrm{C}$ for $10 \mathrm{~min}$ and the supernatant was collected (Yu et al., 2014). The precipitate was re-extracted with $5 \mathrm{~mL}$ of $0.8 \% \mathrm{NaOH} / 0.1 \mathrm{M} \mathrm{PBS}$ ( $\mathrm{pH} 7.4$ ). The supernatant fractions were combined and adjusted $\mathrm{pH}$ to 7.4. After filtering this solution through a $0.4 \mu \mathrm{m}$ PTFE filter, it was subjected to immunoaffinity clean-up. DAN content in eluate was analyzed by HPLC to estimate the recovery of DAN from real samples by immunoaffinity extraction.

\subsection{High-performance Liquid Chromatography (HPLC) procedure}

A HPLC system (Shimadzu, Japan) equipped with a UV detector was used for the detection and quantification of DAN. The column was Shimpack VP-ODS C18 (250 mm $\times 4.6 \mathrm{~mm})$. Acetonitrile containing $0.05 \mathrm{~mol} / \mathrm{L}$ phosphoric acid (19: 81, v/v) was used as the mobile phase at a flow rate of $1.0 \mathrm{~mL} / \mathrm{min}$. Wavelength of detector was fixed at $280 \mathrm{~nm}$. The standard curve of DAN was constructed with DAN standard solutions at the concentrations of $25,50,100,200,300$ and $500 \mathrm{ng} / \mathrm{mL}$. For each analysis, the injection volume was $20 \mu \mathrm{L}$.

\section{Results and discussion}

\subsection{Generation and characterization of antibody}

As a small molecule compound, DAN can't stimulate the body to produce the corresponding antibody. In order to induce immune response, DAN must be conjugated with a carrier protein to elicit the immune response of an animal to produce the anti-DAN antibody. Considering the active carboxylic acid group in the structure of DAN, N-hydroxysuccinimide active ester method was used in this study. UV spectrum was employed to monitor the effectiveness of conjugation reaction (Cui et al., 2011; Yu et al., 2012). The UV scanning spectrum for DAN-BSA was the combination of DAN and BSA and the absorbance peaks of DAN-BSA also showed a slight shift as compared to those of DAN and BSA (Figure 2), suggesting the successful conjugation between DAN and BSA.

The antibody plays an important role on the potential use of the immunosorbent, whether the immunoaffinity is used for a single analyte or for class-selective purposes. To characterize the antibody, the sensitivity and cross-reactivity of the antibody were determined according to ELISA procedure described above. As shown in Figure 3, the antibody generated in this study exhibited high sensitivity toward DAN with an average $\mathrm{IC}_{50}$ value of $4.56 \mathrm{ng} / \mathrm{mL}$, which is comparable to that of previous studies (Liu et al., 2009; Sheng et al., 2009).

The cross-reactivity of the antibody with another four structurally relevant compounds (Figure 1) was measured by comparison of the $\mathrm{IC}_{50}$ of structurally related compounds with that of DAN. As shown in Table 1, the antibody was very specific

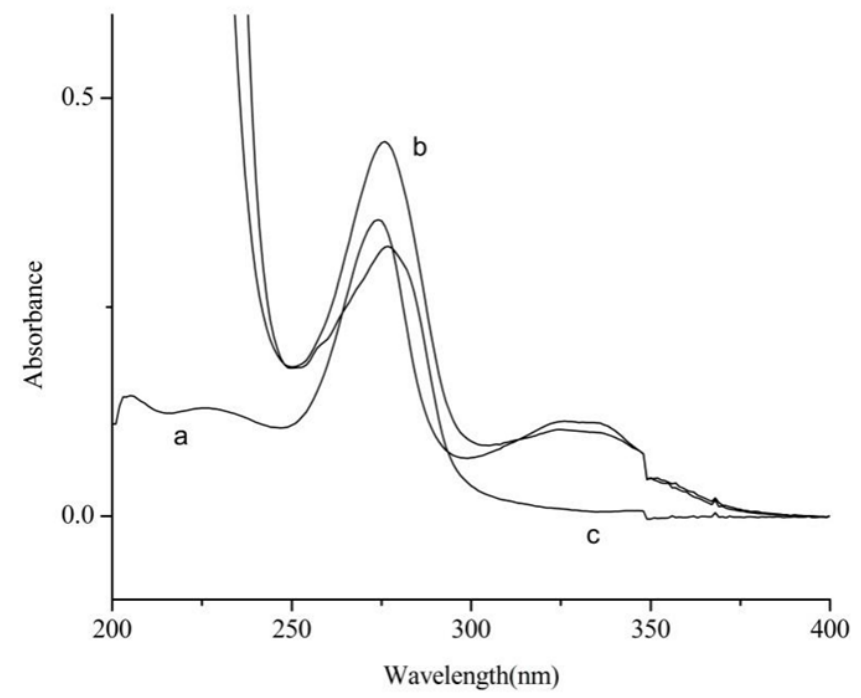

Figure 2. UV scanning spectrums of DAN, BSA and DAN-BSA conjugate. (a) DAN; (b) DAN-BSA; (c) BSA. DAN = danofloxacin; $\mathrm{BSA}=$ Bovine serum albumin . 
to DAN and had negligible cross-reactivity (less than $0.5 \%$ ) toward its analogues. All fluoroquinolones possess a nitrogen-containing, six-membered heterocyclic aromatic ring, a carboxylic group at position 3, a ketone group at position 4 and a fluorine substituent at position 6 (Figure 1). Substituents at positions 1, 7 and 8 differ by compound, which may mainly determine the cross-reactivity of antibody (Wang et al., 2007; Zhao et al., 2007). The poor affinity of the generated anti-DAN antibody toward ENR, NOR, CIP and OFI might be explained by the different substituents at positions 1 and 7 in the structures of these compounds from those of DAN (Cui et al., 2011). Overall, the low $\mathrm{IC}_{50}$ value and poor cross-reactivity against other fluoroquinolones demonstrate the sensitivity and specificity of the obtained antibody.

\subsection{Preparation and characterization of immunoaffinity column}

The immunoaffinity column was prepared by means of directional coupling method (Yang et al., 2016). Chitosan microparticle was employed as a coupling matrix to replace Sepharose $4 \mathrm{~B}$ due to its low cost and biocompatibility. The prepared immunoaffinty column was then evaluated in terms of column binding capacity and column-to-column variety. The column biding capacity was determined by breakthrough volume test. A total of $5 \mathrm{~mL}$ DAN standard solution $(400 \mathrm{ng} / \mathrm{mL})$ were sequentially loaded on the single immunoaffinity column packed with $0.5 \mathrm{~mL}$ adsorbent. DAN in the first two 1-mL DAN standard solutions was nearly completely retained on the column, and about $50 \mathrm{ng}$ of DAN was observed in the effluent when the third 1-mL of DAN standard solution was loaded. Therefore, the column binding capacity of the immunoaffinity column for DAN was approximately estimated to be: $[2 \times 400$ (completely retained) +350 (partially retained) $] / 0.5=2300 \mathrm{ng} / \mathrm{mL}$ gel.

To evaluate the column-to-column variety, 100, 200 and $400 \mathrm{ng}$ of DAN standard solutions were respectively loaded on six immunoaffinity columns and the DAN content in the elution fractions was detected by HPLC and compared with the total loading amounts. As shown in Table 2, the recoveries of DAN

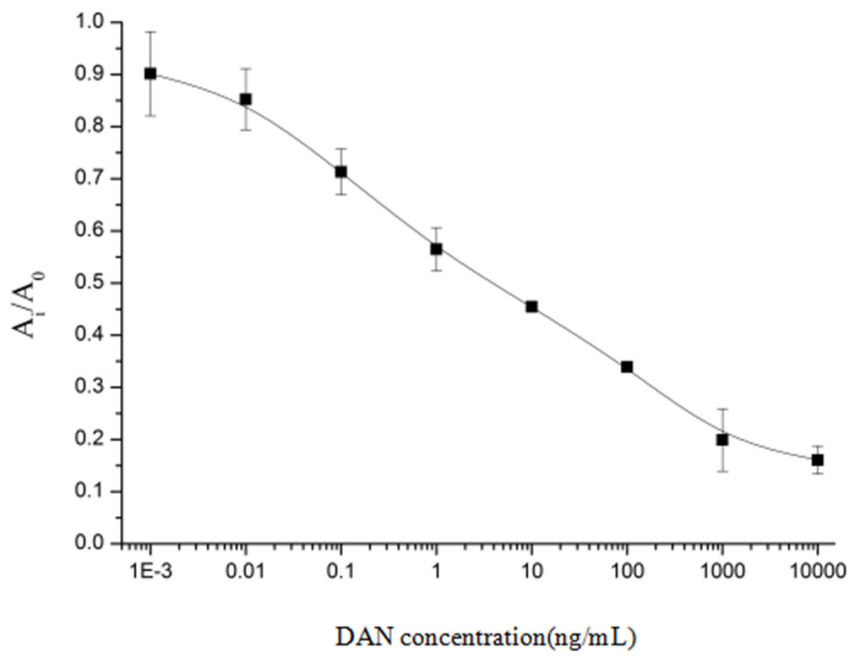

Figure 3. Inhibition curve of anti-DAN polyclonal antibody with DAN as a competitor. ranged from $84.9 \%$ to $95.5 \%$ for all columns with the relative standard deviation (RSD) among columns of 3.7\%, indicating the prepared immunoaffinity columns functioned similarly when challenged with different levels of DAN.

\subsection{Application of immunoaffinity column to extraction of DAN from food samples}

The influence of matrix on the immunoaffinity chromatography cleanup was further studied. Milk samples were fortified at two concentration levels of DAN ( 25 and $50 \mathrm{ng} / \mathrm{g}$ ) according to the maximum residue limit (100 ng/g) accepted by European Union and the Ministry of Agriculture of China. The representative HPLC chromatogram of milk sample and milk sample spiked with DAN after immunoaffinity extraction is illustrated in Figure 4. It was apparent that after immunoaffinity clean-up, the target analyte was specifically retained on IAC and the matrix effect was almost removed (Figure $4 \mathrm{~b}$ ) as compared with that of milk sample (Figure 4a). The spiking results were presented in Table 3, and it can be found that the recoveries of DAN from

Table 1. $\mathrm{IC}_{50}$ and cross-reactivity of anti-DAN polyclonal antibody against structurally related compounds.

\begin{tabular}{cccccc}
\hline & DAN & ENR & NOR & OFL & CIP \\
\hline $\mathrm{IC}_{50}(\mathrm{ng} / \mathrm{mL})$ & 4.56 & $>1000$ & $>1000$ & $>1000$ & $>1000$ \\
$\mathrm{CR}(\%)$ & 100 & $<0.5$ & $<0.5$ & $<0.5$ & $<0.5$ \\
\hline
\end{tabular}

DAN = danofloxacin; ENR = enrofloxacin; NOR = norfloxacin; OFL = ofloxacin; CIP $=$ ciprofloxacin .

Table 2. Column-to-column varieties of immunoaffinity columns.

\begin{tabular}{ccc}
\hline Column Identity & $\begin{array}{c}\text { Detected amount } \\
\text { (ng) }\end{array}$ & $\begin{array}{c}\text { Recovery } \\
(\%)\end{array}$ \\
\hline 100 ng of DAN standard applied & & \\
1 & 84.9 & 84.9 \\
2 & 89.3 & 89.3 \\
200 ng of DAN standard applied & & \\
3 & 175.7 & 87.9 \\
4 & 184.3 & 92.2 \\
400 ng of DAN standard applied & & \\
5 & 350.7 & 87.7 \\
6 & 382.0 & 95.5 \\
Average recovery & $89.6 \pm 3.7$ & \\
\hline DAN = danofloxacin & &
\end{tabular}

DAN $=$ danofloxacin.

Table 3. Extraction recoveries of DAN from spiked food samples by immunoaffinity cleanup.

\begin{tabular}{ccccc}
\hline Sample & $\begin{array}{c}\text { Fortified level } \\
\text { (ng/g) }\end{array}$ & $\begin{array}{c}\text { Found level } \\
(\text { ng/g) }\end{array}$ & $\begin{array}{c}\text { Recovery } \\
(\%)\end{array}$ & $\begin{array}{c}\text { Relative } \\
\text { standard } \\
\text { deviation (\%) }\end{array}$ \\
\hline Milk & 25 & 22.8 & 91.3 & 4.1 \\
& & 24.2 & 96.8 & \\
& \multirow{2}{*}{50} & 24.7 & 98.8 & \\
& & 41.9 & 83.8 & 2.6 \\
& & 42.3 & 84.6 & \\
\hline
\end{tabular}

DAN $=$ danofloxacin. 

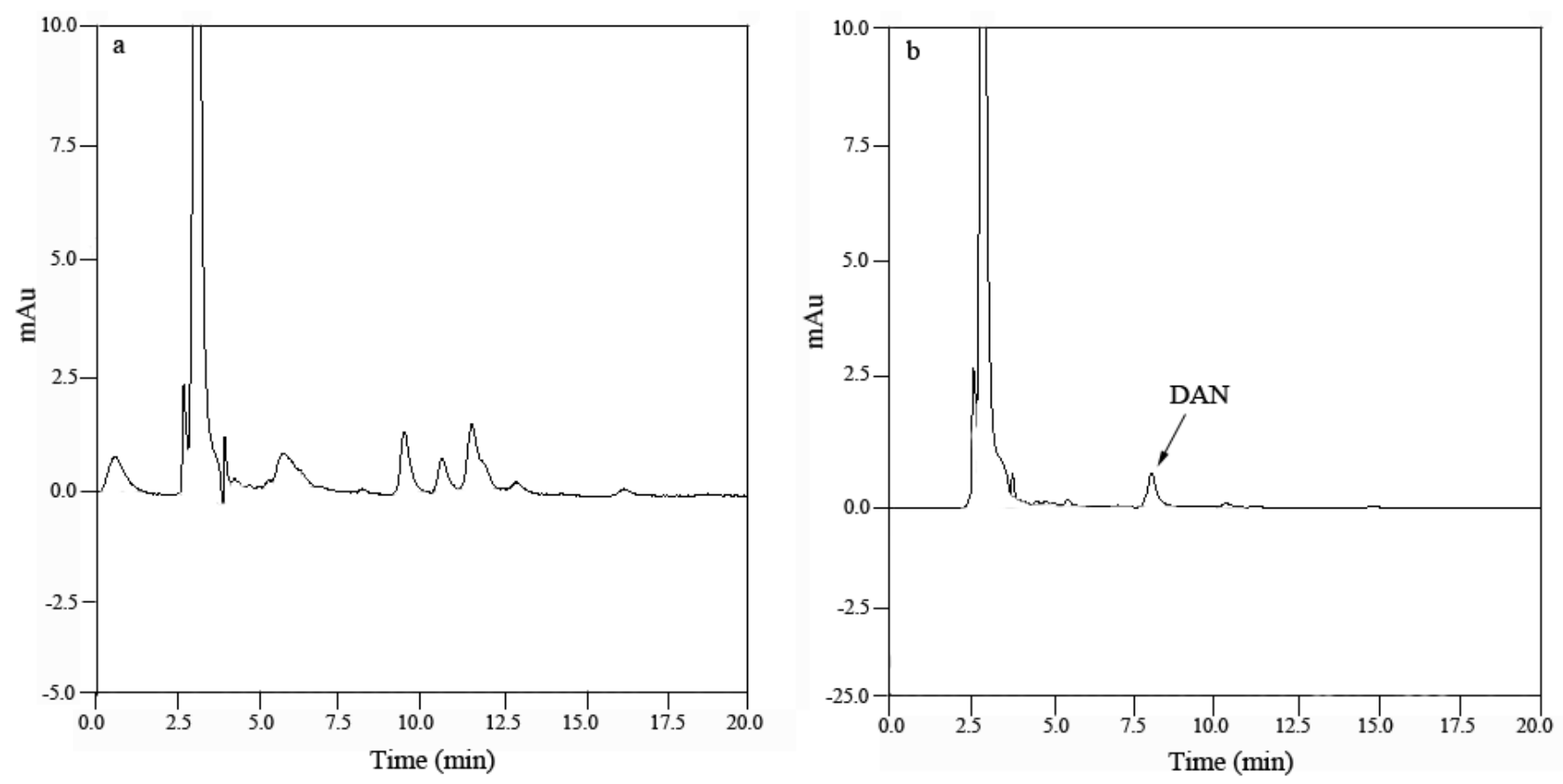

Figure 4. Typical HPLC chromatogram of milk sample (a) and milk sample spiked with DAN (25 ng/g) after immunoaffinity chromatography clean-up (b). HPLC = High-performance Liquid Chromatography.

the fortified milk samples ranged from $83.8 \%$ to $98.8 \%$ with RSD less than $4.1 \%$, demonstrating the feasibility of the prepared IAC column for sample clean-up and DAN quantification.

\section{Conclusions}

In this study, IAC for selective extraction and enrichment of trace DAN was prepared by covalently coupling the generated anti-DAN antibody with chitosan microparticles. The obtained IAC showed a column binding capacity of $2300 \mathrm{ng} / \mathrm{mL}$ gel and less than $3.7 \%$ of column-to-column variability. The IAC was further challenged with real samples and the recovery rates of DAN in milk samples ranged from $83.8 \%$ to $98.8 \%$ with coefficient variation less than $4.1 \%$. In addition, the generated immunoaffinity extraction can be finished in about $15 \mathrm{~min}$, and about 30 samples can been handled per day when the immunoaffinity extractions were performed one after another. The generated immunoaffinity clean-up followed by HPLC analysis offers the advantages in terms of simplicity, efficiency, repeatability and analysis time making it an alternative method for determining DAN in complex sample media.

\section{Acknowledgements}

This work was supported by National Key Technology Research and Development Program of China (2015BAK45B00) and Zhenjiang Sci-Tech Project (NY2017012).

\section{References}

Anitha, A., Sowmya, S., Kumar, P. T. S., Deepthi, S., Chennazhi, K. P., Ehrlich, H., Tsurkan, M., \& Jayakumar, R. (2014). Chitin and chitosan in selected biomedical applications. Progress in Polymer Science, 39(9), 1644-1667. http://dx.doi.org/10.1016/j.progpolymsci.2014.02.008.
Chen, Y., Wang, X., Wang, J., \& Tang, S. (2009). Preparation of acetochlor antibody and its application on immunoaffinity chromatography cleanup for residue determination in peanuts. Journal of Agricultural and Food Chemistry, 57(17), 7640-7643. http://dx.doi.org/10.1021/ jf9017614. PMid:19681614.

Cui, J., Zhang, K., Huang, Q., Yu, Y., \& Peng, X. (2011). An indirect competitive enzyme-linked immunosorbent assay for determination of norfloxacin in waters using a specific polyclonal antibody. Analytica Chimica Acta, 688(1), 84-89. http://dx.doi.org/10.1016/j. aca.2010.12.030. PMid:21296209.

Dorival-García, N., Junza, A., Zafra-Gómez, A., Barrón, D., \& Navalón, A. (2016). Simultaneous determination of quinolone and $\beta$-lactam residues in raw cow milk samples using ultrasound-assisted extraction and dispersive-SPE prior to UHPLC-MS/MS analysis. Food Control, 60, 382-393. http://dx.doi.org/10.1016/j.foodcont.2015.08.008.

Esteve-Turrillas, F. A., Mercader, J. V., Agullo, C., Abad-Somovilla, A., \& Abad-Fuentes, A. (2011). Development of immunoaffinity columns for pyraclostrobin extraction from fruit juices and analysis by liquid chromatography with UV detection. Journal of Chromatography A, 1218(30), 4902-4909. http://dx.doi.org/10.1016/j.chroma.2011.03.022. PMid:21477805.

Huet, A. C., Charlier, C., Tittlemier, S. A., Singh, G., Benrejeb, S., \& Delahaut, P. (2006). Simultaneous determination of (fluoro) quinolone antibiotics in kidneymarine products, eggs, and muscle by enzyme-linked immunosorbent assay(ELISA). Journal of Agricultural and Food Chemistry, 54(8), 2822-2827. http://dx.doi.org/10.1021/ jf052445i. PMid:16608195.

Lara, F. J., Garcia-Campana, A. M., Ales-Barrero, F., Bosque-Sendra, J. M., \& Garcia-Ayuso, L. E. (2006). Multiresidue method for the determination of quinolone antibiotics in bovine raw milk by capillary electrophoresis tandem mass spectrometry. Analytical Chemistry, 78(22), 7665-7673. http://dx.doi.org/10.1021/ac061006v. PMid:17105157. 
Li, Y. L., Hao, X. L., Ji, B. Q., Xu, C. L., Chen, W., Shen, C. Y., \& Ding, T. (2009). Rapid determination of 19 quinolone residues in spiked fish and pig muscle by high-performance liquid chromatography (HPLC) tandem mass spectrometry. Food Additives and Contaminants A, 26(3), 306-313. http://dx.doi.org/10.1080/02652030802484851. PMid:19680903.

Licata, A., Randazzo, C., Morreale, I., Butera, G., D’Alessandro, N., \& Craxi, A. (2012). Fluoroquinolone-induced liver injury: three new cases and a review of the literature. European Journal of Clinical Pharmacology, 68(5), 525-532. http://dx.doi.org/10.1007/s00228011-1201-6. PMid:22246188.

Liu, Z., Lu, S., Zhao, C., Ding, K., Cao, Z., Zhan, J., Ma, C., Liu, J., \& Xi, R. (2009). Preparation of anti-danofloxacin antibody and development of an indirect competitive enzyme-linked immunosorbent assay for detection of danofloxacin residue in chicken liver. Journal of the Science of Food and Agriculture, 89(7), 1115-1121. http://dx.doi. org/10.1002/jsfa.3514.

Longobardi, F., Iacovelli, V., Catucci, L., Panzarini, G., Pascale, M., Visconti, A., \& Agostiano, A. (2013). Determination of ochratoxin A in wine by means of immunoaffinity and aminopropyl solid-phase column cleanup and fluorometric detection. Journal of Agricultural and Food Chemistry, 61(8), 1604-1608. http://dx.doi.org/10.1021/ jf303068m. PMid:22954202.

Lu, S., Zhang, Y., Liu, J., Zhao, C., Liu, W., \& Xi, R. (2006). Preparation of anti-pefloxacin antibody and development of an indirect competitive enzyme-linked immunosorbent assay for detection of pefloxacin residue in chicken liver. Journal of Agricultural and Food Chemistry, 54(19), 6995-7000. http://dx.doi.org/10.1021/jf061309q. PMid:16968054.

Marley, E., Brown, P., Mackie, J., Donnelly, C., Wilcox, J., Pietri, A., \& Macdonald, S. (2015). Analysis of sterigmatocystin in cereals, animal feed, seeds, beer and cheese by immunoaffinity column clean-up and HPLC and LC-MS/MS quantification. Food Additives and Contaminants A, 32(12), 2131-2137. PMid:26515281.

Martinez, M., McDermott, P., \& Walker, R. (2006). Pharmacology of the fluoroquinolones: a perspective for the use in domestic animals. Veterinary Journal, 172(1), 10-28. http://dx.doi.org/10.1016/j. tvj1.2005.07.010.

Mei, L. Y., Cao, B. Y., Yang, H., Xie, Y., Xu, S. M., \& Deng, A. P. (2014). Development of an immunoaffinity chromatography column for selective extraction of a new agonist phenylethylamine A from feed, meat and liver samples. Journal of Chromatography B: Analytical Technologies in the Biomedical and Life Sciences, 945-946, 178-184. http://dx.doi.org/10.1016/j.jchromb.2013.11.057. PMid:24342511.

Pichon, V., \& Combes, A. (2016). Selective tools for the solid-phase extraction of Ochratoxin A from various complex samples: immunosorbents, oligosorbents, and molecularly imprinted polymers. Analytical and Bioanalytical Chemistry, 408(25), 6983-6999. http:// dx.doi.org/10.1007/s00216-016-9886-0. PMid:27585915.

Qiao, Y., Yang, H., Wang, B., Song, J., \& Deng, A. (2009). Preparation and characterization of an immunoaffinity chromatography column for the selective extraction of trace contraceptive drug levonorgestrel from water samples. Talanta, 80(1), 98-103. http://dx.doi.org/10.1016/j. talanta.2009.06.029. PMid:19782197.

Şenyuva, H. Z., \& Gilbert, J. (2010). Immunoaffinity column clean-up techniques in food analysis: a review. Journal of Chromatography B: Analytical Technologies in the Biomedical and Life Sciences, 878(2), 115-132. http://dx.doi.org/10.1016/j.jchromb.2009.05.042. PMid:19525155.

Sheng, W., Xu, T., Ma, H., Wang, X., Li, Q., \& Li, J. (2009). Development of an indirect competitive enzyme-linked immunosorbent assay for detection of danofloxacin residues in beef, chicken and pork meats. Food and Agricultural Immunology, 20(1), 35-47. http:// dx.doi.org/10.1080/09540100802657581.

Stoilova, N. A., Surleva, A. R., \& Stoev, G. (2013). Simultaneous determination of nine quinolones in food by liquid chromatography with fluorescence detection. Food Analytical Methods, 6(3), 803-813. http://dx.doi.org/10.1007/s12161-012-9488-1.

Sun, L., Mei, L., Yang, H., Zhao, K., Li, J., Jiang, D., Li, M., \& Deng, A. (2016). Development and application of immunoaffinity column for the simultaneous determination of norfloxacin, pefloxacin, lomefloxacin, and enrofloxacin in swine and chicken meat samples. Food Analytical Methods, 9(2), 342-352. http://dx.doi.org/10.1007/ s12161-015-0192-9.

Vakili, M., Rafatullah, M., Salamatinia, B., Abdullah, A. Z., Ibrahim, M. H., Tan, K. B., Gholami, Z., \& Amouzgar, P. (2014). Application of chitosan and its derivatives as adsorbents for dye removal from water and wastewater: A review. Carbohydrate Polymers, 113, 115-130. http://dx.doi.org/10.1016/j.carbpol.2014.07.007. PMid:25256466.

Wang, S., Mu, H., Bai, Y., Zhang, Y., \& Liu, H. (2009). Multiresidue determination of fluoroquinolones, organophosphorus and N-methyl carbamatessimultaneously in porcine tissue using MSPD and HPLCDAD. Journal of Chromatography B: Analytical Technologies in the Biomedical and Life Sciences, 877(27), 2961-2966. http://dx.doi. org/10.1016/j.jchromb.2009.07.011. PMid:19646932.

Wang, Y., Xu, Y., Zhang, X., Wang, E., \& Dong, Y. (2011). Development and characterization of a chitosan-supported immunoaffinity chromatography column for the selective extraction of methandrostenolone from food and feed samples. International Journal of Biological Macromolecules, 49(3), 428-432. http://dx.doi.org/10.1016/j.ijbiomac.2011.05.027. PMid:21664371.

Wang, Z., Zhu, Y., Ding, S., He, F., Beier, R. C., Li, J., Jiang, H., Feng, C., Wan, Y., Zhang, S., Kai, Z., Yang, X., \& Shen, J. (2007). Development of a monoclonal antibody-based broad-specificity ELISA for fluoroquinolone antibiotics in foods and molecular modeling studies of cross-reactive compounds. Analytical Chemistry, 79(12), 4471-4483. http://dx.doi.org/10.1021/ac070064t. PMid:17511422.

Wilcox, J., Donnelly, C., Leeman, D., \& Marley, E. (2015). The use of immunoaffinity columns connected in tandem for selective and cost-effective mycotoxin clean-up prior to multi-mycotoxin liquid chromatographic-tandem mass spectrometric analysis in food matrices. Journal of Chromatography A, 1400, 91-97. http://dx.doi. org/10.1016/j.chroma.2015.04.053. PMid:25990350.

Xu, X., Liu, L., Jia, Z., \& Shu, Y. (2015). Determination of enrofloxacin and ciprofloxacin in foods of animal origin by capillary electrophoresis with field amplified sample stacking-sweeping technique. Food Chemistry, 176, 219-225. http://dx.doi.org/10.1016/j.foodchem.2014.12.054. PMid:25624227.

Xu, Z., Deng, H., Lei, H., Jiang, Y., Campbell, K., Shen, Y., Yang, J., Wang, H., \& Sun, Y. (2012). Development of a broad-specificity monoclonal antibody-based immunoaffinity chromatography cleanup for organophosphorus pesticide determination in environmental samples. Journal of Agricultural and Food Chemistry, 60(23), 58475852. http://dx.doi.org/10.1021/jf300896z. PMid:22612520.

Yang, Y., Wang, Y., Niu, R., Lu, J., Zhu, X., \& Wang, Y. (2016). Preparation and characterization of chitosan microparticles for immunoaffinity extraction and determination of enrofloxacin. International Journal of Biological Macromolecules, 93(Pt A), 783-788. http://dx.doi. org/10.1016/j.ijbiomac.2016.09.041. PMid:27640092.

Yao, K., Zhang, W., Yang, L. Y., Gong, J. F., Li, L., Jin, T. M., \& Li, C. (2015). Determination of 11 quinolones in bovine milk using immunoaffinity stir bar sorptive microextraction and liquid chromatography with 
fluorescence detection. Journal of Chromatography B: Analytical Technologies in the Biomedical and Life Sciences, 1003, 67-73. http:// dx.doi.org/10.1016/j.jchromb.2015.09.008. PMid:26415000.

Yu, F., Wua, Y., Yu, S., Zhanga, H., Zhang, H., Qu, L., \& Harrington, P. D. (2012). A competitive chemiluminescence enzyme immunoassay for rapid and sensitive determination of enrofloxacin. Spectrochimica Acta. Part A: Molecular Spectroscopy, 93, 164-168. http://dx.doi. org/10.1016/j.saa.2012.03.001. PMid:22472132.

Yu, F., Yu, S., Yu, L., Li, Y., Wu, Y., Zhang, H., Qu, L., \& Harrington, P. B. (2014). Determination of residual enrofloxacin in food samples by a sensitive method of chemiluminescence enzyme immunoassay. Food Chemistry, 149, 71-75. http://dx.doi.org/10.1016/j. foodchem.2013.10.024. PMid:24295678.
Zhang, Z., Hu, X., Zhang, Q., \& Li, P. (2016). Determination for multiple mycotoxins in agricultural products using HPLC-MS/MS via a multiple antibody immunoaffinity column. Journal of Chromatography B: Analytical Technologies in the Biomedical and Life Sciences, 1021, 145-152. http://dx.doi.org/10.1016/j.jchromb.2016.02.035. PMid:26948441.

Zhao, C., Liu, W., Ling, H., Lu, S., Zhang, Y., Liu, J., \& Xi, R. (2007). Preparation of anti-gatifloxacin antibody and development of an indirect competitive enzyme-linked immunosorbent assay for the detection of gatifloxacin residue in milk. Journal of Agricultural and Food Chemistry, 55(17), 6879-6884. http://dx.doi.org/10.1021/ jf070978g. PMid:17645343. 